\title{
NON-DESTRUCTUVE TESTING OF WOOD STRUCTURES BY X-RAYS
}

\section{A B S S T R A C}

This work examines the possibility of detecting the weak points of wood structure assembly by non-destructive methods and restoring it, in a timely manner, before it comes to visible damaging. This is the purpose of using X-ray examination for the samples of three types of wood: ring-porous deciduous, diffuse porous deciduous and conifers. The hypothesis was that the permeability of wood to X-ray radiation was inversely proportional to the coefficient of static resistance of wood. The mechanical properties of wood samples used in this work are approximates of their table values of coefficient of static bending stress expressed in MPs. In proving these hypotheses, X-ray machine was used, with a range of work from $40-125 \mathrm{kV}$ and $0.50=360 \mathrm{~m} \mathrm{~A} / \mathrm{s}$, the same as its usage in humane medicine. This work showed that by X-rays we could successfully establish quality properties of certain types of wood and by that its best usage, which is, for example, of special interest for restoration and reconstruction of objects of cultural and historical value. Non-destructive methods of testing wood structure assembly certainly justify their role in that field and they require further research and development.

\section{Andrej Josifovski}

Dijana Savanović

KEY WORDS

University of Belgrade - Faculty of Architecture

NON-DESTRUCTIVE METHODS

X-RAY RADIATION

WOOD STRUCTURE

DEFECTS

RESTORATION 


\section{INTRODUCTION}

Non-destructive testing of physical properties of wood is of particular importance for preparing and planning the restauration works on buildings. Discovering hidden damages in wood structure would provide timely restoration of the building, which would prevent unexpected disturbance of stability and, consequently, its collapsing. Regular, systematic diagnostics, would, accordingly, be a condition of preservation of stability and autentic exterior. Commencing the building restauration at the moment when visible damages of structure have already appeared, usually requires large work operations on the building, which would condition long term construction works and it would, accordingly, demand significantly higher financial investment. Discovering potentially weak points of wood structural assemblies and their focused restoration, and by that significantly lower investment, would secure preserving authenticity of objects of cultural and historical importance.

The goal of this work is to evaluate the possibility of non-destructive testing of quality of wood structural assembly of culturally and historically important buildings. Providing planned reconstruction of these buildings would, accordingly, be the final goal. The first step towards it is to conduct X-ray testing of wood samples with familiar mechanical characteristics, analogically to destructive determining mechanical characteristics of wood, and by that its constructive application. The research goal is to prove the hypothesis that for the "hardwood" more intensive X-ray radiation would be necessary, as well as longer exposure of the sample to radiation, so as to detect certain changes or artifacts in its structure. The research goal is to establish dependence between mechanical characteristics of the wood with physical quantities that are measurable by non-destructive methods and the quantities that are possible to be delivered out of them.

The tasks of the work are:

1. Proving the hypothesis that permeability of rays through wood depends on its hardness.

2. Proving the hypothesis that each wood has unequal permeability of X-rays because of their anisotropy.

3. Proving the hypothesis that anisotropy of construction is the lowest with diffuse porous deciduous trees.

4. 4. Proving the hypothesis that the wood density is different in axial and radial direction (stump).

5. Proving the hypothesis that the X-ray permeability is proportional to the coefficient of static bending stress. 
6. Proving the hypothesis that X-rays, because of the unequal permeability through different environments, detect defects inside wood.

7. Proving the hypothesis that hardwood has lighter radiograph.

8. Proving the hypothesis that the radiograph quality of wood is directly dependent on the radiant intensity $(\mathrm{kV})$ and the length of exposition of the radiographed object $(\mathrm{mA} / \mathrm{s})$.

\section{MATERIALS AND METHODS}

For non-destructive estimation of wood hardness, samples of three different types of wood will be used: conifer, ring-porous deciduous trees and diffuse porous deciduous trees. The selection of samples will be such that from each group we take wood with highest and lowest middle value of coefficient of static bending stress, expressed in $\mathrm{MPa}{ }^{2}$

The test samples will be made of remains of the cut wood construction, so there will be no equal structural representation of late wood in all samples. Since the mechanical properties of wood samples used in working approximates of their table values, the values of coefficient of static bending stress will not be considered an absolute indicator of its hardness. It will be acquired that static stress in wood pressure is ten times higher when the compression is in direction of parallel longitude of the fibers, in relation to stress caused by compression which is perpendicular to fibers' direction. Firmness under compression is an indicator of wood hardness and its density. In this case, density is a property which determines the degree of permeability of X-ray radiation. In addition to the compression stress, tension stress because of the bending occur as well, and this is why the coefficient of static bending stress will be considered as more precise indicators of mechanical properties of the wood.

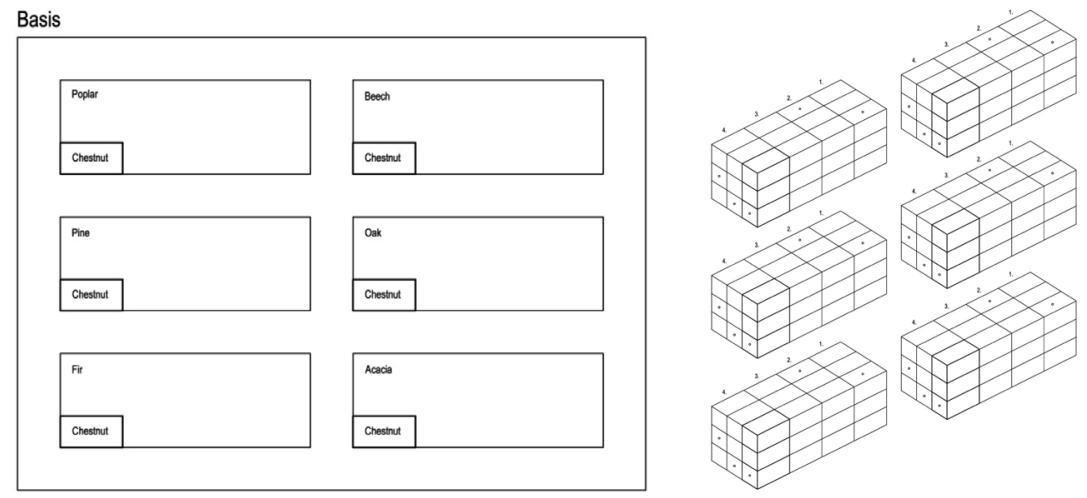

Figure 1. Wood samples for testing 
The testing will be conducted on testing samples (plaques) of the same

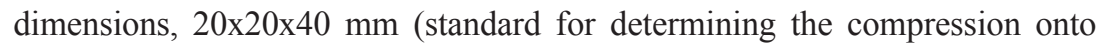
wood stress, parallel to the fibres JUSD.A.I 0.45). The testing samples will be cut so that on ones the direction of the fibers length will be the same as the longest axis, whereas with the others it will be perpendicular in relation to it.

One of the samples in each group will be cross-drilled along the axis of symmetry, while the perforated directions will be crossed under the angle of $90^{\circ}$ in a point of symmetrical cross section, horizontal, transverse and sagittal planes. Perforations will be made by a drill with a diameter of $1.5 \mathrm{~mm}$.

The samples will be divided into three groups, and each of them will have two sub-groups of twelve packs with three samples per each. Samples in the control group are made from pieces of beams of chestnut tree delivered from Hilandar, by the same principles as the rest of the sub-groups. In the first group, we will test samples of ring-porous deciduous, acacias (150 MPs) and oak tree (88 MPs). The second group will have samples of diffuse porous deciduous, beech (123 MPs) and Canadian poplar (60 MPs), and the third group consists of conifer - pine tree (100 MPs) and fir (73 MPs). The control group consists of samples of chestnut tree (63.5 MPs) which was used as a material for wood assembly of the Hilandar Monastery (Figure 1).

In the first sub-group of each group, there are wood samples with the highest coefficient, and in the second are the samples of those with the lowest coefficient. Pack of the first sub-group will contain samples of acaias, and the first subgroup - samples of oak tree. The second sub-group will contain samples of beech, the second sub-group - samples of Canadian poplar, while the third subgroup will contain the samples of pine tree, and the third sub-group - samples of fir. The samples will be stocked in a line, one next to the other:

- The first A1 pack - All three samples with the fibers' direction are parallel with the longest axis, only with the perforated sample on the top;

- The first B1 pack - all three samples with the fibers' direction are parallel with the longest axis, and the perforated sample is in the middle of the pack;

- The first C1 pack - all three samples with the fibers' direction are parallel with the longest axis, and the perforated sample is in the bottom of the pack;

- The first D1 pack - all three samples with the fibers' direction are perpendicular to the longest axis, and the perforated sample is on the top of the pack;

- The first E1 pack - all three samples with the fibers' direction are perpendicular to the longest axis, and the perforated sample is in the middle of the pack; 
- The first F1 pack - all three samples with the fibers' direction are perpendicular to the longest axis, and the perforated sample is in the bottom of the pack;

- The first G1 pack - the upper sample in the pack is with the fibers' direction parallel to the longest axis, while the next two with the fibers' direction perpendicular to the longest axis, with the perforated sample in the middle;

- The first H1 pack - the upper sample in the pack is with the fibers' direction parallel to the longest axis, while the next two with the fibers' direction perpendicular to the longest axis, with the perforated sample in the bottom;

- The first K1 pack - the upper two samples with the fibers' direction parallel to the longest axis, while the last, perforated sample, with the fibers' direction, perpendicular to the longest axis;

- The first L1 pack - upper and lower sample with the fibers' direction perpendicular to the longest axis, while the middle, perforated sample is with the fibers' direction parallel to the longest axis;

- The first M1 pack - the upper two samples with the fibers' direction perpendicular to the longest axis, while the lower, perforated sample, with the fibers' direction, parallel to the longest axis.

The packs of the rest of the sub-groups will be elaborated by the same principle as the one in the first sub-group.

Each group contains two sub-groups with 11 packs, and each pack has three samples. One group consists of 66 samples, where 32 are with fibers' direction parallel to the longest axis, and 10 are perforated, with 34 with fibers' direction perpendicular to longest axis, and 12 are perforated. The testing samples are made of semi-dry wood, which is characterised by certain amount of moisture

\section{Basis}

\begin{tabular}{|l|l|l|l|}
4. & 3. & 2. & 1. \\
\hline & & ${ }^{3}$ & \\
\hline & & & \\
\hline & & & $\circ$ \\
\hline
\end{tabular}

\section{Sections}
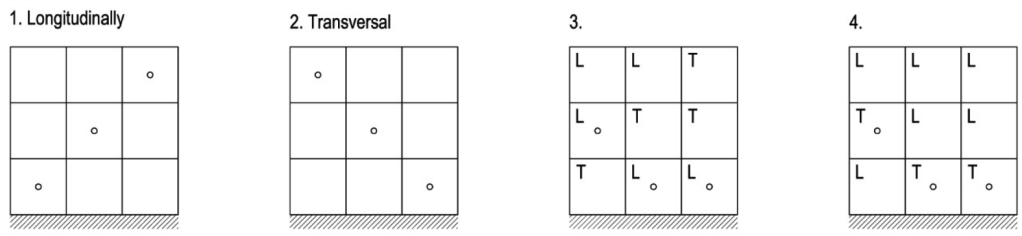

Figure 2. Projections of group set of wood samples 
according to the environment where the wood is. The presupposed state of the wood is of $12-16 \%$ of hygroscopic moisture, i.e. the wood in terms of stationed cut built. The moisture data is provided from the literature, and it was obtained under lab conditions, by measuring with electrical hygrometer GANN with the measuring range up to $100 \%$ of moisture. The samples' creation is standardised in relation to axial intersection, dimensions and moisture.

The testing of samples is conducted by short X-ray scanning of certain energy and the duration of exposure. Since the X-ray machine chosen for this procedure is the one used in humane medicine, with the range of $40-125 \mathrm{kV}$ and 0.50 $360 \mathrm{~mA} / \mathrm{s}$, analogically to its usual application, the upper limit of working range will be $100 \mathrm{kV}$ and $70 \mathrm{~mA} / \mathrm{s}$. The layout of packs of each sub-group will be in formation $4-4-3+1 \kappa$, where the first two lines with the first three samples homogeneous, with parallel or perpendicular direction of fibers onto the longitudinal axis, plus one pack, where the upper sample with the opposite orientation of the fibers' direction in relation to the first three in a row of that line of packs. In the last, inhomogeneous line, all four packs, taking into the pack of the control group, have in the first row samples with an opposite orientation of axial direction of fibers (longitudinal) in relation to the axial direction of the fibers (perpendicular) of the first three packs in the second row, plus the control group pack. The third row is conditionally inhomogeneous, since on the last position there is always a homogeneous pack of chestnut samples of the transverse orientation. Since the pack alignment is being done alphabetically from left to right, until the fourth position in the row, vertical columns of three packs, plus homogenous control pack of transverse orientation, have the configuration of samples of inhomogeneous packs. In the second phase of testing, there will be two parallel sets, longitudinal and transverse cut packs from each group, with homogenous packs of control group in the end. Three homogenous packs of longitudinal orientation of fibers in certain sub-groups will be in the first set, placed next to each other, starting from diffuse porous deciduous of highest coefficient of static compression stress, until conifers, ending with packs of control group, while in the other set there will be the same layout of the packs, but with the samples that have transverse orientation of fibers. Such sets, considering the differences in coefficients of pressure stress of particular samples, should visually provide the zebra model. Both sets will be scanned by X-rays of medium and high strength ( 70 and $100 \mathrm{kV}$, and 37 and 70 $\mathrm{mA} / \mathrm{s})$. In the end, in one collected group, without any particular order, only mix the layout of inhomogeneous packs of samples. This set will be scanned only by the X-rays of medium power ( $70 \mathrm{kV}$ and $37 \mathrm{~mA} / \mathrm{s})$. X-ray projection of this set would provide visual model of mosaic. Confirmation of different permeability of X-rays, depending on density, i.e. firmness of the wood, numerically expressed 
by static stresses in wood, should be achieved by simultaneous analysis of individual and group sets of selected samples, organised according to their coefficients, of static compression stress.

Perforations made in certain samples, modularly represent damages in the wood, and the depth of their visibility, assumingly, is proportional to the hardness of the wood.

The accuracy of this hypothesis will be examined through each of the sets being scanned by X-rays of minimal, medium, and maximum power, of usual diagnosic range of medical usage $(40,70$ and $100 \mathrm{kV}$, or 4, 37 and $70 \mathrm{~mA} / \mathrm{s})$ with a focus distance of $114 \mathrm{~cm}$.

Since the mechanical properties of wood samples used in work, their approximate table value and their creation being standardised only in relation to axial cross and dimensions, with the presence of subjectivity while comparing the radiographs, it could be considered limiting in delivering conclusions.

\section{RESULTS AND DISCUSSION}

By radiographing the samples of all three types of wood: diffuse porous deciduous, ring-porous deciduous and conifer, we get visible difference in light between homogenous packs of samples cut longitudinally to the axis of the fibers in the first row, and homogenous packs of samples cut in a perpendicular way from the second row. The difference in brightness of homogenous packs from the first rows compared to all the other packs is also present. Gradually, it is the least expressed in the first set, which provides the brightest image where we can see packs of hardest diffuse porous deciduous, beech (Figure 3).

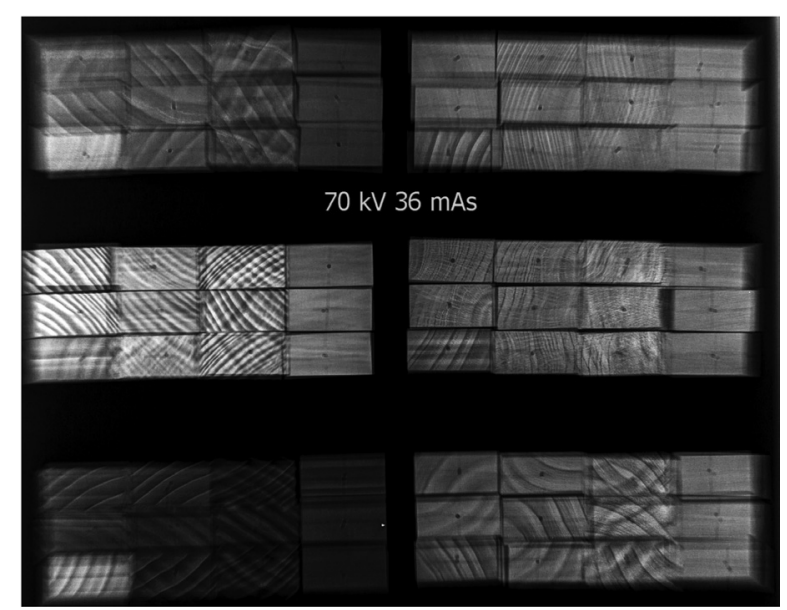

Figure 3. Scanned image of group set of wood samples 
1. Keeping in mind that with this type of deciduous involvement of mechanical elements towards density and hardness is not clearly manifested, according to the width of ring growth, than, considering the slower growth of beech and larger equability of its density, such image is expected. The last in line is, the darkest of all, scanned image of set of the softest conifer - fir. If we take that the wood stress that is caused by compression paralleled with fibers (beech 62 MPs, Canadian poplar 34.5 MPs, acacias 73 MPs, oak tree $61 \mathrm{MPs}$, pine tree $55 \mathrm{MPs}$, fir $47 \mathrm{MPs}$ ) almost 10 times bigger than the one caused by perpendicular compression (beech 6.2 MPs, Canadian poplar 3.4 MPs, acacias 7.3 MPs, oak tree 6.1 MPs, pine tree 5.3 MPs, fir $4.7 \mathrm{MPs}$ ) and then, according to it, wood is the hardest in that axial direction. Since the focus of X-rays on the second row of packs of all sets axial (parallel to the fibers' direction), the image in that part is the brightest, which is directly proportional to coefficient of static compression stress, i.e. hardness of wood.

The set of the last sample of wood (conifer - fir, the lowest level of hardness) deviates from it. Conifers have a significant difference in hardness of early and late wood, and because of the quicker growth, fir's content of later wood (which states the degree of hardness) proportionally smaller. Because of large permeability of X-rays and dark image, the second row of homogenous packs of samples looks even darker, since the crossing of shadows of radiant structures is the highest there, in the relation to inhomogeneous packs. $\mathrm{X}$-rays fall under wider angle onto the final set, so the sharper lines of that part of image are thicker. Because of that, the developing power of that kind of image is weaker. This darkness is projected illusion and not deviation from the rules, which is proven by the last two rows of inhomogeneous packs that appear lighter than the second row.

The first three sets of samples of different types of deciduous, acacias (73 $M P s)$, oak tree $(61 M P s)$ and beech (62 MPs) have the brightest projections, which fits their coefficients of static compression stress. By the light tonality, images of beech and oak tree are almost of the same coefficients, even though they are the different species. The projection of the conifer pine tree set (55 MPs) compared to projections of these three deciduous, looks brighter, even though its coefficient is lower than the one of deciduous. Since there is a large amount of resin, which impregnates the walls of cells of the conifer pine tree and which is layered in the lumen of anatomical elements, contrast differences which are spotter on projections of their packs are the biggest, which definitely represents one of the reasons of such visualisation. 
By comparing projections of chestnut samples packs (30.5 MPs) from the control set, we can see that, by the light tonality, they are pretty similar to projections of basic sets of acacias, oak, beech, and that they are of weaker intensity from the pine sets, stronger than the poplar set, and significantly brighter than the fir projection sample. The table value of the coefficient of compression stress is the lowest with chestnut. The last in line of heterogenic packs has in its layout upper two samples with longitudinally oriented fibers, which explains this visual manifestation.

Since the samples of longitudinally oriented fibers, because of their smaller mechanical hardness have easier permeability of X-rays, their projection becomes softer. Compared to this, homogenous pack of control group of transverse orientation of fibers will have significantly bigger mechanical hardness, i.e. the brighter reflection. The moisture content of wood significantly influences its mechanical properties, and the coefficient of bending stress could be reduced to over $60 \%$, by changing the moisture from 12 to $30 \% .^{3}$ The presupposed moisture content of cut structure from which the samples are taken is $12 \%$ at minimum, which is, compared to moisture of ancient wood construction of chestnut wood in Hilandar (out of which control samples are made), significantly bigger. The period of drying the cut structure, if we disregard pre-usage preparations, is incomparably longer, when it comes to control sample of chestnut. Since the relation of coefficient of compression stress and bending stress of control chestnut about 1:2.8, than the brightness of the image of control sample will be proportional to coefficients and significantly more intense than the samples of other sets. This is supported by the fact that the set of control set provides the similar projection display, as well as the other settings, with more brightness of image of transversely oriented samples. Radiograph of diffuse porous deciduous beech wood sample ( $62 \mathrm{MPs}$ ) is almost not different at all from the image of ring-porous deciduous oak wood (61 MPs), which almost have the same value of coefficients of compression stress. The zebra model appeared as it is supposed, in the projection of group set of samples which were scanned by X-rays of medium power (Figure 4).

The coefficient of static compression stress of Canadian poplar, the fourth in line in set, is by its value the closest to the coefficient of the chestnut. The coefficient of the poplar is lower than the coefficient of the pine tree, while the coefficient of the chestnut is lower than the coefficient of the fir.

The footage of these same sets by X-rays of highest power gives visual model of tonal palette, which has more moderate appearance with samples of longitudinal orientation of fibers (Figure 5). 
X-rays of greater power have bigger penetration strength, so by increasing the power to the degree of certain strength, it equally passes through all structures. By that, mechanical hardness of transversely oriented samples is bigger, so their permeability is lower. This is why the projection of packs of samples of longitudinal orientation of fibers, in this case, is of more moderate contrast differences.

2. Radiography of homogenous sets of samples cut perpendicularly in the direction of fibers, as the images of inhomogeneous sets of all sets, leave the impression of networks of dark panes. The network contract is particularly emphasised in rows of inhomogeneous sets where projections of axial and radial structures are crossed, of newer and older wood, as well as the wood tracks. Since the anisotropy is significantly emphasised in radial than in axial direction of tree trunks, ${ }^{4}$ the appearance of network is visible only on radiographic display of sets cut perpendicularly of the fibers' direction.

With diffuse porous deciduous wood, the regularity of relation of width of rings grows and the participation of mechanical elements, according to density and hardness of wood is not shown clearly every time. The size of trachea with these species is slowly reduces according to the borders of the ring growth. This is how in the example of beech, because of its slower growth, we do not spot the big difference in light intensity of images of sets of samples cut perpendicularly and transversely, whereas poplar, which grows significantly faster, gives X-ray footage of ring-porous deciduous and conifer wood. Instead of the image of network (Figure 6), the broom trace of beech samples cut perpendicularly is being shown (author's note).

3. As provided in the formulation, the coefficient of anisotropy stands in the same relation as the values of coefficients of compression stress, parallel and perpendicular to the fibers and it is $1: 10 .{ }^{5}$ The proof of that minimal axial anisotropy of wood is almost the same image of projection of homogenous sets of samples, cut parallel in the direction of fibers', in all sets, including the control one (the first row in all given sets, Figure 1). Opposite to that, there is a preview of colorful network of samples, cut perpendicularly in the direction of fibers.

4. Static resistance of wood is equivalent to stress that appears in gradual rise of pressure in the time interval from 2 to 5 minutes. It reflects the wood hardness and it is being measured by the value of coefficient of compression stress, which appears in the function of that time. As the projection images 


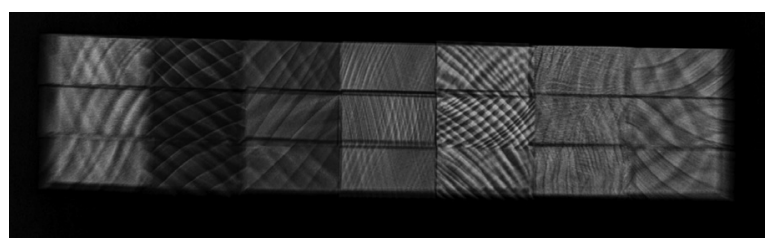

Figure 4 . The zebra model

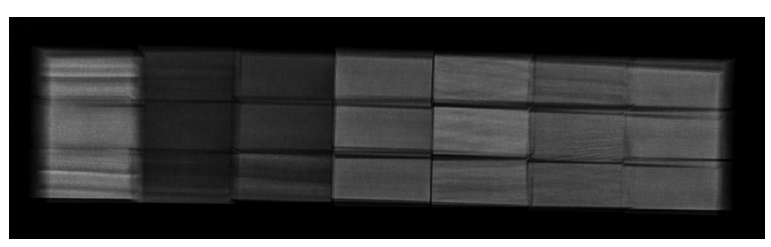

Figure 5. Model of tonal palette

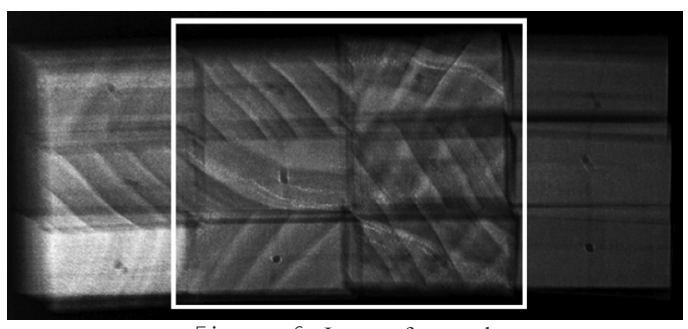

Figure 6. Image of network

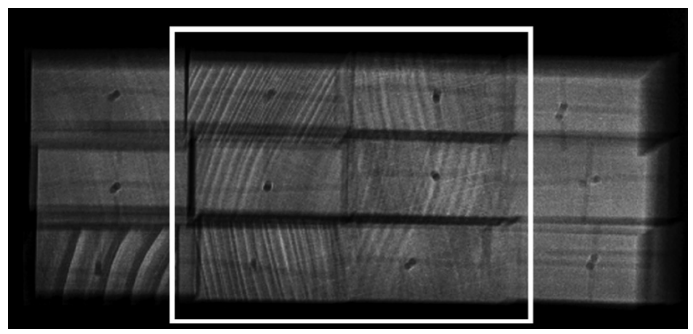

Figure 7 . The broom trace of beech samples 
of sets of different samples of wood have the same contrast configurations, and different sharpness, depending in the applied power and length of radiographic exposure, permeability of X-rays is proportional to coefficient of static resistance of the wood. ${ }^{6}$

5. Projections of made perforations in particular samples are visible in all sets, but they are of significantly "softer" contours than the ones that belong to structural assembly. With greater increasing the power of X-rays, only the shapes of the hardest structural elements are preserved, which is presupposed, considering the difference in density of wood and air. By darkening the image, the softest contours are the first to disappear.

6. Harder wood has bigger density, and the specific density determines the degree of absorption of X-rays. According to that, wood with more specific image will have brighter projection image. This is analogue to greater hardness, i.e. darkening the projection image, by increasing power and radiographic exposure.

7. The quality of wood radiograph is directly proportional to strength of X-rays and the length of exposure radiographed object. Depending on the specific density, i.e. the hardness of wood, by increasing the power and the length of exposure, the quality of radiograph will also increase, up until the optimal value. In this research, that optimal image quality is achieved by the power of X-rays of $70 \mathrm{kV}$ and exposure of $37 \mathrm{~mA} / \mathrm{s}$.

\section{CONCLUSION}

The analysis of radiographs of individual and collective sets, for deciduous as well as for the conifer types of wood, confirms the thesis about unequal permeability of X-rays through wood of different density, in terms of static pressure stress or hardness of the wood. Since the wood is characterised by anisotropy of structure, in axial and radial direction as well, inhomogeneous radiographs perpendicularly are less emphasised, due to the coefficient of static compression stress.

With diffuse porous deciduous that anisotropy of built is the lowest, which is rightly reflected onto homogeneity of radiographs of their structural assembly. As the degree of anisotropy of wood depends on its mechanical characteristics and structure, and as the mechanical elements determine the hardness degree, it results that the permeability of X-rays is directly proportional to coefficient of static resistance of wood. ${ }^{7}$ Analogically, because of the unequal permeability 
of X-rays, their penetration through structures of different density, we detect irregularities and defects in the wood texture. Wood defects in the radiograph are darker, because of the bigger specific density of wood compared to air. It results in radiograph of harder wood is always brighter, compared to softer wood. Since the permeability of X-rays perpendicularly proportional to the wood density, i.e. its hardness, it means that we must use only one particular part of X-ray specter for detection of anisotropy and the defects in wood.

In the end, we may only conclude that non-destructive testing of mechanical properties of wood has a perspective application even with the most delicate demands of evaluating woods' quality. Reconstruction and restoration of objects of cultural and historical importance, whose structural assembly is based on wood constructions, is one of the possible fields of applying this method. The results of this work may serve as guidelines for further improvement of using non-destructive diagnostics of mechanical characteristics of wood. Complete objectification of this procedure is in conjunction with improvement of diagnosis technology, which would contribute to preserving world cultural and historical heritage. 
Babić, Radomir. Radiology. Belgrade: Medicinska knjiga, 2002.

Muravljov, Mihailo. Construction Materials. Belgrade: Gros knjiga, 1995.

Novelline, Robert. Squire's Fundamentals of Radiology 5. London: Harvard University Press, 1997.

Purić, Jagoš and Ivan Dojčinović. Physics of Atoms. Belgrade: Zavod za udžbenike, 2013.

Šš̌kić, Borislav and Zdravko Popović. Wood Properties. Belgrade: The Faculty of Forestry, 2002. 


\section{MODEL PREVENTIVNE RESTAURACIJE ARHITEKTONSKIH OBJEKATA UPOTREBOM ČELIKA I STAKLA}

\section{Jefto Terzović, Rastislav Mandić}

U radu je predložen koncept projektovanja seizmički otpornih arhitektonskih objekata, upotrebom nekonvencionalnih materijala - lameliranog stakla i lameliranog klirita, u cilju preventivne restauracije. Predloženim konceptom projektovanja, lamelirano staklo i lamelirani klirit, predviđeni su kao ispuna u čeličnom ramu, na koji naležu posredstvom intermedijalnog sloja gume, čime se formira kompozitni sklop. Na taj način se formiraju vertikalni elementi ukrućenja, integrisani u konstruktivni sistem objekta, osposobljeni za prijem seizmičke sile. Primenljivost takvog sistema, proverena je eksperimentom u laboratorijskim uslovima, gde su eksperimentalni modeli na bazi lameliranog stakla i lameliranog klirita izlagani dejstvu cikličnog opterećenja, koje simulira seizmičku silu.

KLJUČNE REČI: PREVENTIVNA RESTAURACIJA, LAMELIRANO STAKLO / KLIRIT, SEIZMIČKA UKRUĆENJA, LABORATORIJSKO ISPITIVANJE, RAČUNARSKA ANALIZA

\section{NEDESTRUKTIVNO ISPITIVANJE DRVETA RENDGENSKIM ZRACIMA Andrej Josifovski, Dijana Savanović}

Rad ispituje mogućnost blagovremenog detektovanja slabih tačaka drvenog konstruktivog sklopa, nedestruktivnim metodama, radi sanacije, pre nego što nastanu njegova vidljiva oštećenja. U tu svrhu korišćeno je rendgensko ispitivanje uzoraka tri vrste drveta: prstensasto poroznih lišćara, difuzno poroznih lišćara i četinara. Pretpostavka je bila da je propusnost drveta za rendgenske zrake obrnuto srazmerna koeficijentu statičke otpornosti drveta. Mehanička svojstva uzoraka drveta korišćenih u radu su aproksimacija njihovih tabelarnih vrednosti koeficijenata statičkog naprezanja drveta izraženih u MPa. Za dokazivanje ovih hipoteza korišćen je rendgen aparat sa opsegom rada od 40-125 kV i $0.50=360 \mathrm{~mA} / \mathrm{s}$ istovetno njegovoj primeni u humanoj medicini. Ovim radom se pokazalo da se rentgenskim zracima može uspešno utvrđivati kvalitativno svojstvo određene vrste drveta, a time i njegova najbolja upotrebljivost, što je na primer, od posebnog interesa za restauraciju i obnovu objekata od kulturnog i istorijskog značaja. Nedestruktivne metode ispitivanja drvenog konstruktivnog sklopa, svakako opravdavaju svoju ulogu na tom polju i nameću zahtev njihovog daljeg usavršavanja. 